\begin{tabular}{|c|c|c|c|c|c|c|}
\hline \multirow{4}{*}{ Impact Factor: } & ISRA (India) & $=3.117$ & SIS (USA) & $=0.912$ & ICV (Poland) & $=6.630$ \\
\hline & ISI (Dubai, UAI & $=0.829$ & РИНЦ (Russia & $=0.156$ & PIF (India) & $=1.940$ \\
\hline & GIF (Australia) & $=0.564$ & ESJI (KZ) & $=8.716$ & IBI (India) & $=4.260$ \\
\hline & JIF & $=1.500$ & SJIF (Morocce & $=5.667$ & OAJI (USA) & $=0.350$ \\
\hline
\end{tabular}

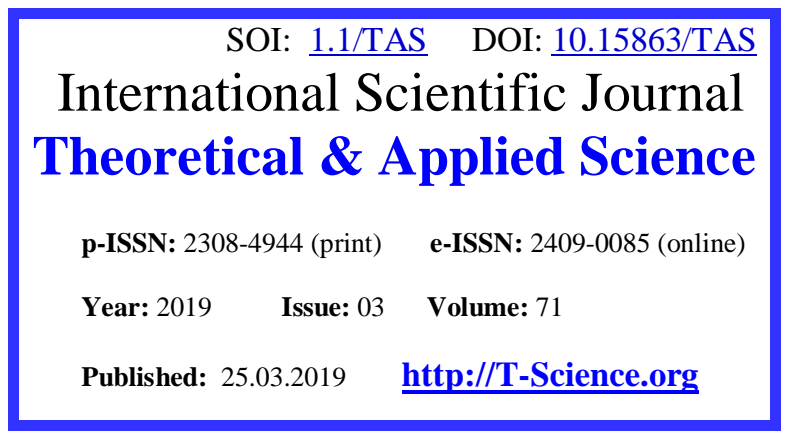

SECTION 31. Economic research, finance, innovation, risk management.
QR - Issue

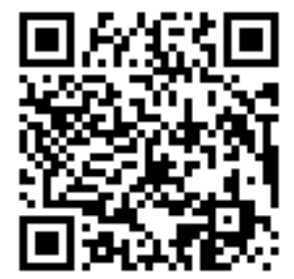

\title{
PRINCIPLES OF TIES OF INTERNAL CONTROL AND MANAGEMENT ACCOUNTING SYSTEMS AT THE ENTERPRISES OF BLACK METALLURGY
}

\section{senior researcher of "Accounting" department, \\ Tashkent State University of Economics, \\ Republic of Uzbekistan, Tashkent city}

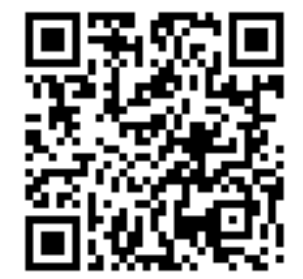

Abstract: This article analyzes the role of ferrous metallurgy in the world and in the Republic of Uzbekistan, the organization of management accounting and internal control in the industry, as well as the existing problems of management accounting in the steel industry. Also, based on the theoretical analysis of various approaches, a number of economists were based on the author's approach to the internal control system in the management process, elements of internal control, forms of control and their components. control.

Key words: ferrous metallurgy, management accounting, internal control, control processes, analysis, internal

Language: English

Citation: Abdusalomova, N. B. (2019). Principles of ties of internal control and management accounting systems at the enterprises of black metallurgy. ISJ Theoretical \& Applied Science, 03 (71), 385-391.

Soi: http://s-o-i.org/1.1/TAS-03-71-30 Doi: crossef https://dx.doi.org/10.15863/TAS.2019.03.71.30

\section{Introduction}

The important role of the industry in maintaining the country's competitiveness on the world market, and first of all, necessitates the accounting of accounts and management accounts, which are part of the metallurgical industry's internal requirements. The introduction of the internal control system, which is an integral part of management accounting, plays an important role in this.

In the world ferrous metallurgy industry, there are groups of countries that currently supply raw materials, produces and consumes finished metal products. According to the World Steel Association (WSA), production of ferrous metal (steel) in 64 countries increased by $1.0 \%$ in January 2019, reaching 146.7 mill. tons [23].

In our Republic, ferrous metallurgy is one of the leading sectors of the economy. The prevalence of ferrous metallurgy in Uzbekistan at the present stage of economic development is a nationwide priority. Decree of the President of the Republic of Uzbekistan No. 4124 of January 17, 2019 "On Measures to Improve the Management System of Uzmetkombinat" of the President of the Republic of Uzbekistan No. 3277 of September 15, 2017 "On measures to further improve the activities of mining and metallurgical enterprises On measures for improvement of the order of work with waste and scrap of non-ferrous and ferrous metals "dated June 6, 2018 of the Cabinet of Ministers of the Republic of Uzbekistan № 425 the decision [3] is aimed at improving production management efficiency and introducing modern methods of corporate governance.

\section{Literature review}

As a result of the research, management accounting and control systems at the enterprises of the ferrous metallurgy industry have identified major difficulties in managing complex network constraints: the absence of a system of distribution of powers among the parent and affiliated companies; Difficulty in managing the business through simultaneous performance of several types of activities (production, processing and sale of metal products); a sophisticated system of supervision and incentives for affiliates; different types of production processes by different types of activities, and, consequently, due to the lack of coordination between different methods of accounting for expenditure and financial results.

Researchers in field of textile small business was researched by economists as well as Ibragimov I., Hakimov Z., Tursunov B. [20-22] and others. 


\begin{tabular}{|c|c|c|c|c|c|c|}
\hline \multirow{4}{*}{ Impact Factor: } & ISRA (India) & $=3.117$ & SIS (USA) & $=0.912$ & ICV (Poland) & $=6.630$ \\
\hline & ISI (Dubai, UAE & $=0.829$ & РИНЦ (Russia) & $=0.156$ & PIF (India) & $=1.940$ \\
\hline & GIF (Australia) & $=0.564$ & ESJI (KZ) & $=8.716$ & IBI (India) & $=4.260$ \\
\hline & JIF & $=1.500$ & SJIF (Morocco) & $=5.667$ & OAJI (USA) & $=0.350$ \\
\hline
\end{tabular}

The information required for management is derived from accounting and other non-accountable sources. An optimal system for receiving information is a management account. The management account consists of a number of elements: budgeting, responsibilities, management (internal) reporting, management (internal) analysis, management control, management accounting automation system, and more.

An internal audit system may be a separate management function of an entity, or internal control may be viewed as a subset of management accounts as it has been observed in theory and practice lately. This creates an opportunity to obtain additional information on the management accounting system, and the use of new methods in the internal audit system.

Accounting for the purposes of management will be closely linked to the management system as part of the overall economic system of enterprises in the ferrous metallurgy industry. Theoretical approaches allow you to enter the system of accounting, which is associated with the grouping of certain objects required for management in accounting. These are long and short-term (current) assets, private equity, other transactions that arise in the process of economic activity.

In the accounting process of these objects the following functions are carried out: information, control, analysis and others. In turn, accounting objects are functionally interconnected.

In the economic literature on accounting, there is a different opinion on the essence of accounting objects. Some authors argue that "as an element of the accounting system elements of its method, including accounts, are involved" [4]. In our opinion, the functional link between the accounting elements (elements) of accounting will be made using the elements of the accounting method. They can be described as tools used to carry out accounting functions and tasks.

\section{Analysis and results}

The objective of accounting is dependent on the management system. Because the management system includes various functions, accounting is organized according to these features. The main purpose of accounting is to classify information for various management functions.

L. Voronina, an economist with economics, believes that accounting for business entities should be based on the function of maintaining and maintaining a general cycle of management with all other functions of its management cycle [5].

In our opinion, the goal is to solve two accounting tasks: to create information conditions for planning, economic analysis, control, forecasting and regulation, and to implement the functions of the management apparatus of enterprises of the ferrous metallurgy industry, its affiliates, structural subdivisions upgrade In its turn, the management account is based on the results of the analysis of the received and processed information. For regulatory purposes, input and output flows need to be streamlined. At the same time, the management system collaborates with the organization and functional divisions managed through a management service. Management decisions are taken on the basis of information obtained and affect the management system. The management objects are an indoor cycle, which generates economic processes, resources, production volumes, production costs, benefits, and thus forms an accounting system. The managing system (parent) is affected by the pro forma, planning, organizational work, accounting, control, analysis, decision-making (see Figure 1) on a managed entity (subsidiary). 


\begin{tabular}{llllll} 
& ISRA (India) $=\mathbf{3 . 1 1 7}$ & SIS (USA) & $=\mathbf{0 . 9 1 2}$ & ICV (Poland) & $=\mathbf{6 . 6 3 0}$ \\
Impact Factor: & ISI (Dubai, UAE) $=\mathbf{0 . 8 2 9}$ & PUHU (Russia) $=\mathbf{0 . 1 5 6}$ & PIF (India) & $=\mathbf{1 . 9 4 0}$ \\
& GIF (Australia) $=\mathbf{0 . 5 6 4}$ & ESJI (KZ) & $=\mathbf{8 . 7 1 6}$ & IBI (India) & $=\mathbf{4 . 2 6 0}$ \\
& JIF & $\mathbf{1 . 5 0 0}$ & SJIF (Morocco) $=\mathbf{5 . 6 6 7}$ & OAJI (USA) & $\mathbf{0 . 3 5 0}$ \\
\hline
\end{tabular}

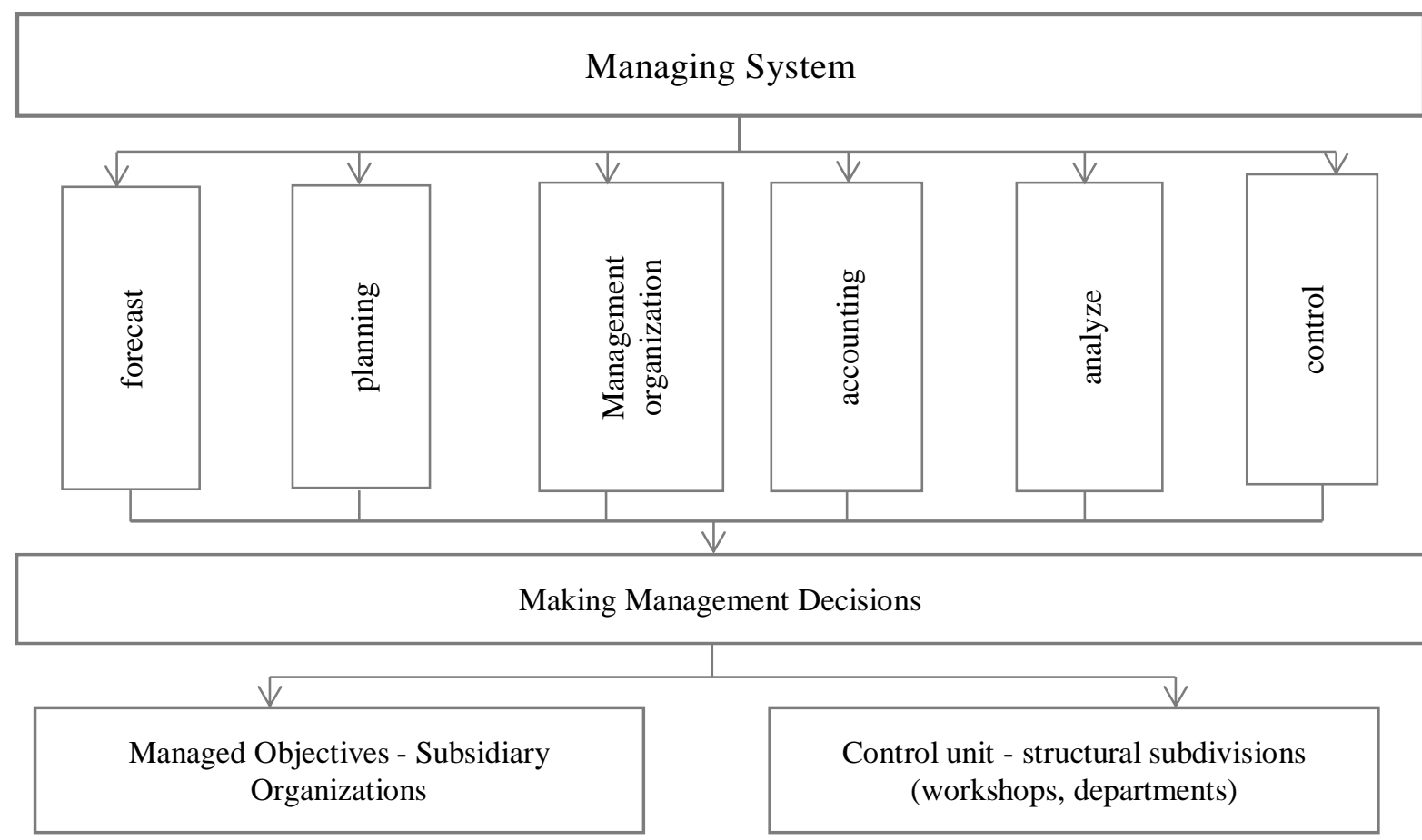

Fig.1. Influence of the management system on the management object of the ferrous metallurgy industry

As a result of the research conducted by the author, it can be concluded that there is a great lack of information in the management of enterprises of the ferrous metallurgy industry, which is due to inaccuracies in timely information, inadequate information and often inadequate information management. This, in turn, reduces the quality of management. Consequently, it is necessary to activate research related to the information system focused on the problem of data collection and processing. Based on this information, management accounting and control has been developed and options for managing decision-making are developed and many choices are selected from a suitable decision. The next step is the implementation of the adopted decision, ie the development of measures aimed at the production element to achieve the planned budget performance. The closing step is to obtain information about the status of the object or process, to identify the budget deficits and to develop information for the next step.

As a result, the adoption of management decisions on the basis of economic information on accountability will be step-by-step. Stages of management decisions are shown in Figure 2.

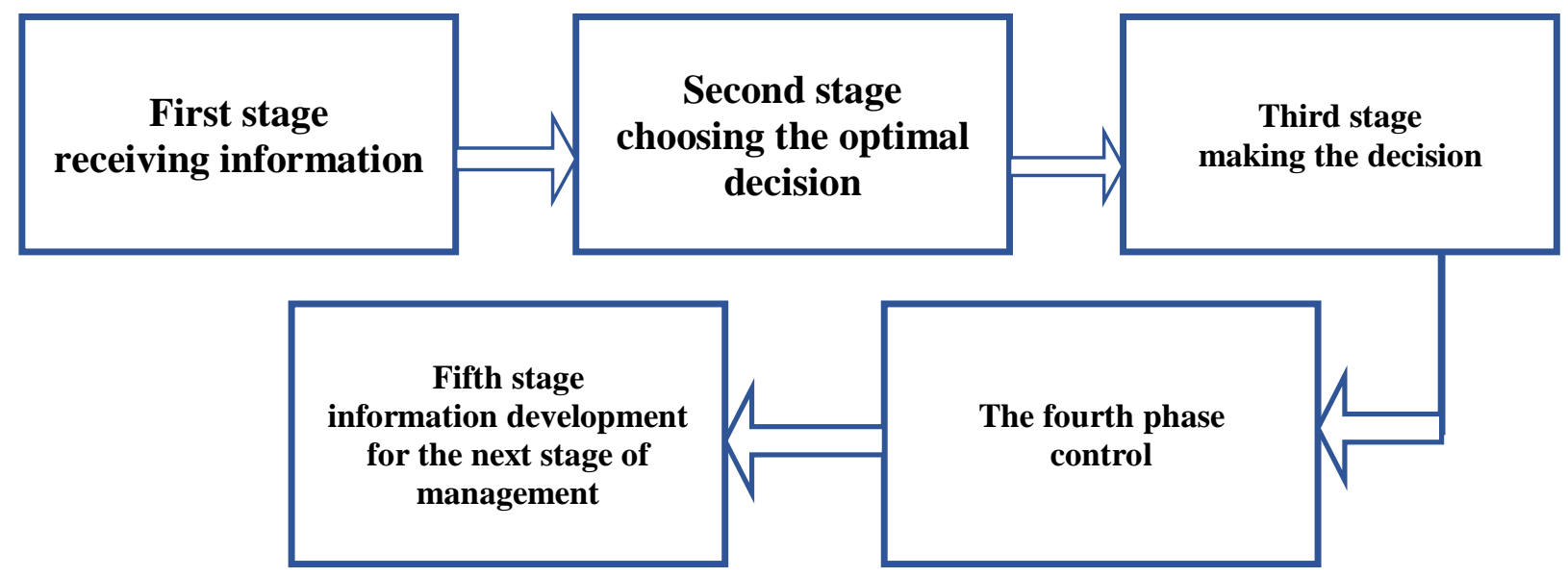

Fig. 2. Stages of management decisions based on management accounting information 


\begin{tabular}{|c|c|c|c|c|c|c|}
\hline \multirow{4}{*}{ Impact Factor: } & ISRA (India) & $=3.117$ & SIS (USA) & $=0.912$ & ICV (Poland) & $=6.630$ \\
\hline & ISI (Dubai, UAE & $=0.829$ & РИНЦ (Russia) & $=0.156$ & PIF (India) & $=1.940$ \\
\hline & GIF (Australia) & $=0.564$ & ESJI (KZ) & $=8.716$ & IBI (India) & $=4.260$ \\
\hline & JIF & $=1.500$ & SJIF (Morocco) & $=5.667$ & OAJI (USA) & $=0.350$ \\
\hline
\end{tabular}

The accounting information collection phase is an analytical accounting, it must be of immediate effect. The level of accuracy is defined by the ratio of the time required for the initial work to be done, the initial documentation, the management's initial workflow, the time required to work with the original accounting documents, at the time of the accounting information for all stages of the accounting.

Accounting implies execution of restricted control functions, which involves controlling the activity of individuals, organizations, banks and settlements in the budget, the correct representation of business transactions in the accounting records, and so on.

Connection with control and planning functions is reflected in the implementation of management decisions, and implementation of economic and financial plans. Supervision over the validity of the plan's indicators helps to increase the optimality of production planning and forecasting.

Consequently, the control is not only bound by an analysis but also includes analysis, which means that the analysis should be considered as part of the control.

Formation of the control system, its objectives, tasks, functions and mechanisms of control bodies have been studied by a number of economists.

L. Paramonova, an economist in economics, believes that internal control of a business entity is one of the managerial functions of an entity, and it monitors accounting objects and processes to verify that their activities are consistent with current legislation and regulatory documents [6]. But his opinion is narrower, but the focus is on monitoring. L.A.Rodina, O.V. Kucherenko, VV Zavadskaya, in the opinion of L. Rodina, noted that the organizational structure, methods and measures adopted by the management as an effective management of the enterprise's internal control system in managing accounts [7].

According to K. Durr, control should ensure that the actual situation is assessed accurately and at the same time make the necessary conditions for the change in all the development indicators and separate sections of the enterprise [8]. Consequently, control is one of the most important tools for making decisions that will ensure that the organization operates properly.

In the opinion of A.Kucherov, OV Korobkova, the internal control system is a set of measures for effective functioning of the management of the undertaking, as well as control over compliance with the requirements established by law, timely preparation of reliable financial statements, prevention of errors and omissions, execution of orders, taste of property safety of the organization nlash [9]. But we can see that this description is not complete. In our opinion, the most complete definition given to internal control is the definitions given by A.Kucherov, OV Korobkova, and based on these opinions, we can define internal control forms as follows. The forms of internal control are different, each with a number of elements (Figure 3 ). 


\begin{tabular}{llllll} 
& ISRA (India) $=\mathbf{3 . 1 1 7}$ & SIS (USA) $=\mathbf{0 . 9 1 2}$ & ICV (Poland) & $=\mathbf{6 . 6 3 0}$ \\
Impact Factor: & ISI (Dubai, UAE) $=\mathbf{0 . 8 2 9}$ & PUHЦ (Russia) $=\mathbf{0 . 1 5 6}$ & PIF (India) & $=\mathbf{1 . 9 4 0}$ \\
& GIF (Australia) $=\mathbf{0 . 5 6 4}$ & ESJI (KZ) & $=\mathbf{8 . 7 1 6}$ & IBI (India) & $=\mathbf{4 . 2 6 0}$ \\
JIF & $\mathbf{1 . 5 0 0}$ & SJIF (Morocco) $=\mathbf{5 . 6 6 7}$ & OAJI (USA) & $\mathbf{0 . 3 5 0}$ \\
\hline
\end{tabular}

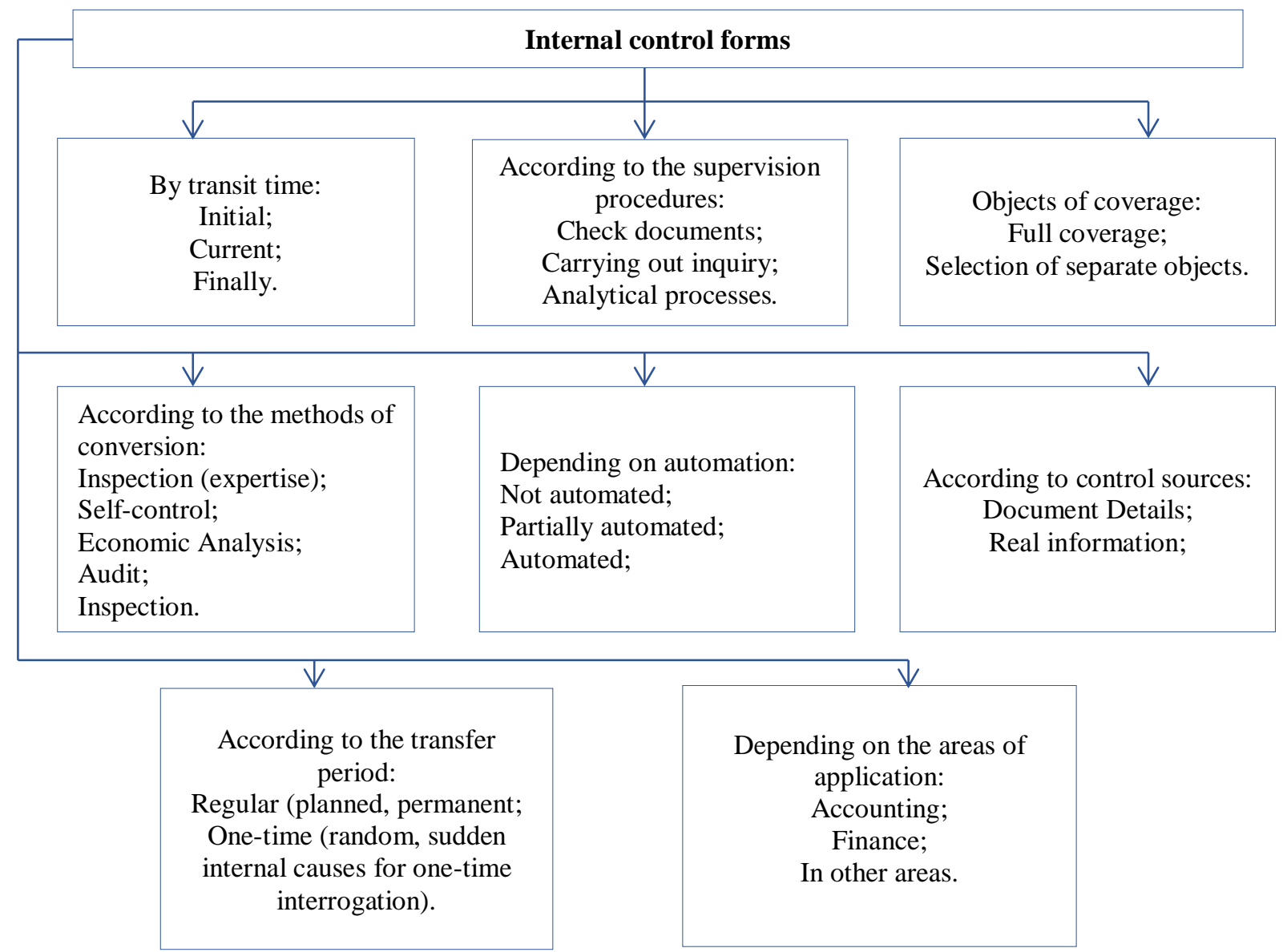

Fig.3. Internal control forms

As you can see from this picture, the internal control is grouped by a few brands. Depending on the location of the management account, it is grouped into groups, such as the audit process, its sources, and the time of the transfer. Of course, this classification correctly identifies the role and place of internal control in the management accounting process. However, identification of the components of internal control makes it possible to optimize internal control in the process of management accounting. That is why we have analyzed various points from our side to examine its components.

At the same time, we can see that there are various approaches to the management of an account of the internal control components:

According to V. Burtsev, the internal control consists of nine parts: 1) subject of control; 2) control object; 3) the principles of control; 4) control methods; 5) management technologies; 6) control process; 7) collection and processing of initial data for control; 8) results of control and expenses for its implementation; 9) Decisions to be taken as a result of a control [10].

According to MV Melnik, internal control consists of five parts: 1) the control environment; 2) risk assessment; 3) control measures; 4) internal communication, monitoring and control subjects; 5) making decisions on the results of the inspection [11].

NK Karzayeva defines the components of internal control as follows: control environment; control tools and control processes; control subjects and information systems [12].

An English scientist R.Dodj stated that "Internal control is an internal audit function that is governed by the firm's decision-making body for control and analysis of economic activities" [13].

Professor M. Pardaev's scientific works "internal audit has been considered as a link to internal control" [14].

According to Professor Ibragimov, the internal audit provides information about the economic activity and confirms the reliability of the farm reports. This audit is primarily necessary to prevent losses, and to make necessary changes within the organization. The importance and necessity of internal audit is related to the analysis of management functions "[15].

According to professor A.A.Karimov, internal audit is one of the indispensable and essential elements of the control of management, its importance 


\begin{tabular}{|c|c|c|c|c|c|c|}
\hline \multirow{4}{*}{ Impact Factor: } & ISRA (India) & $=3.117$ & SIS (USA) & $=0.912$ & ICV (Poland) & $=6.630$ \\
\hline & ISI (Dubai, UAE & $=0.829$ & РИНЦ (Russia & $=0.156$ & PIF (India) & $=1.940$ \\
\hline & GIF (Australia) & $=0.564$ & ESJI (KZ) & $=8.716$ & IBI (India) & $=4.260$ \\
\hline & JIF & $=1.500$ & SJIF (Morocco & $=5.667$ & OAJI (USA) & $=0.350$ \\
\hline
\end{tabular}

and necessity arises from the need for control of business management [16]. BAShasanov claims that "internal audit has financial oversight with financial auditing" [17]. K. Ahmedjanov believes that "internal control is an indispensable element of the control process in each management process, and it is also a system that shows how good it is at other stages and provides information. The internal control system includes all internal documents of the undertakings, ie the production process, the work of sections and shops, as well as the internal legal acts of the general legislative and economic entities regulating the economic activity, as well as production technology, its effectiveness has a direct impact on the outcome of the financial reporting [18].

\section{Conclusions}

In the above-mentioned authors' approaches, we can see that the internal control is reflected in each of the following three elements:

1. Monitoring environment (internal control environment and environmental monitoring), taking into account external and internal factors.

2. Documentation, technical and organizational tools to ensure the controlling processes (control measures or control methods).

3. Information system (initial data, accounting) the system of indicators, software, databases, personnel qualifications and rules of processing of data set by the management of the undertakings.

Containing the above points, we can conclude that, in our opinion, it is desirable to define the internal control components as follows: control functions, control subjects (who controls), control object (controlling), control methods, decision making on the results of audit, the role of staff in decision making, the set of goals and tasks of the individual departments, the internal audit kazım processes, internal control service personnel qualification standards, methods of control and monitoring, accounting and management accounting data, the report concluded, time and frequency of information and communication technologies.

The findings of the research showed that theoretical justification of the main provisions of the structural subdivisions, workshops, main organizational structure of the internal control system, determination of information sources, objectives, content, objects, implementers, methods of implementation of the enterprises of ferrous metallurgy industry to ensure efficiency of use of production resources, it is necessary to develop a method of its application in practice.

The enterprises of the ferrous metallurgy industry have a complex management system to improve their methodology to improve their methodology. The internal control system operating at the parent company is directed primarily at the management of the ferrous metallurgy company to control the activities of affiliated companies and subdivisions, to identify and control the effectiveness of utilization of production resources, and to prevent production risks.

\section{References:}

1. (2017). On measures to improve the management system of Uzmetkombinat of the SPZ-3277, dated 15.09.2017.

2. (2019). Resolution of the Uzbek SSR No. 4124 "On measures to further improve the activities of mining and metallurgical enterprises", dated 17.01.2019.

3. (2018). The Resolution of the Cabinet of Ministers "On Measures to Improve the Order of Working with Parts, Non-Ferrous and Nonferrous Metals," dated 06.06.2018.

4. Sokolov, Y. V., Butynets, F., Goretskaya, L. L., \& Pankov, D. A. (2005). Bukhgalterskiy uchet v zarubezhnykh stranakh. uchebnik. (p.664). Moscow: Athlete; Prospekt.

5. Voronin, L. I. (1997). Budget and financial control and audit. Moscow: Finance and Statistics.
6. Paramonova, L. (2012). Typology and models of the organization of internal control of the economic entity. Resources. Information. Supply. Competition, № 2, 362-365.

7. Motherland, L. A., Kucherenko, O. V., \& Zavadskaya, V. V. (2013). On the issue of internal control in the system of cost management. Bulletin of Omsk University. Economy series, No. 2, 189-192.

8. Drury, K. (2012). Management and production accounting: a textbook. Publisher: Unity-Dana.

9. Kucherov, A. V., \& Korobkova, O. V. (2013). Improving the internal control system. Young scientist, №5, 329-332.

10. Kolesnikova, E. (2010). Formation of a control system in an agricultural production cooperative. Agricultural Economics of Russia, No. 9, 52-54. 


\begin{tabular}{|c|c|c|c|c|c|c|}
\hline \multirow{4}{*}{ Impact Factor: } & ISRA (India) & $=3.117$ & SIS (USA) & $=0.912$ & ICV (Poland) & $=6.630$ \\
\hline & ISI (Dubai, UAE & $=0.829$ & РИНЦ (Russia & $=0.156$ & PIF (India) & $=1.940$ \\
\hline & GIF (Australia) & $=0.564$ & ESJI (KZ) & $=8.716$ & IBI (India) & $=4.260$ \\
\hline & JIF & $=1.500$ & SJIF (Morocco & $=5.667$ & OAJI (USA) & $=0.350$ \\
\hline
\end{tabular}

11. Melnik, M. V., Panteleev, A. S., \& Zvezdin, A. L. (2005). Audit and control. (p.520). Moscow: Publishing House FBK-PRESS.

12. Karzayeva, N. N. (2013). The system of internal control over accounting and preparation of financial statements. Accounting in agriculture, № 10, 65-77.

13. Dodge, R. (1992). A Quick Guide to Standards and Auditing Standards: Trans. from English; Preface S.A.Stukova. (p.240). Moscow: Finance and Statistics; UNITI. (Audit: theory and practice).

14. Pardaev, M. Q. (2001). Theoretical and methodological problems of economic analysis in the conditions of liberalization of economy. Dis iqt fan d-ri. S..

15. Ibragimov, A. K. (2002). Improvement of cost accounting, auditing and cost estimate of agricultural production. Dis.iqt. fan d-ri. Tashkent.

16. Karimov, A. A. (2009). Main areas of accounting and audit improvement in corporate governance. Dis.iqt. fan.d-ri. Tashkent.

17. Khasanov, B. A. (2004). Improve management accounting and internal audit methodology. Dis.iqt. fan d-ri. Tashkent.

18. Akhmedjanov, K. B. (2016). Improve the internal audit methodology in business entities. Dis.iqt. fan d-ri. Tashkent.
19. Tursunov, B. O. (2017). Metody otsenki ekonomicheskoy nadezhnosti tekstil"nogo predpriyatiya $v$ usloviyakh rynochnoy ekonomiki. V sbornike: Teoriya i praktika organizatsii promyshlennogo proizvodstva. Effektivnost' organizatsii i upravleniya promyshlennymi predpriyatiyami: problemy i puti resheniya Materialy Mezhdunarodnoy nauchno-prakticheskoy konferentsii. Voronezhskiy gosudarstvennyy tekhnicheskiy universitet. (p.139-144).

20. Ibragimov, I. U., \& Tursunov, B. O. (2017). Enhancement the mechanism of analyzing of the methodological principles for the development and improvement of methods of assessment. Audit, № 4, 11-13.

21. Tursunov, B. O. (2017). Osnovnye napravleniya podderzhki malogo biznesa v Uzbekistane i zarubezhnyy opyt razvitiya predprinimatel"stva. Audit, № 6, 34-38.

22. Tursunov, B. O. (2017). Perspektivy razvitiya tekstil"noy promyshlennosti v Uzbekistane. Menedzhment $v$ Rossii $i$ za rubezhom, № 4, 7884.

23. (2019). Retrieved 2019, from https://www.worldsteel.org/media-centre/pressreleases/2019/january-2019-crude-steelproduction.html 
ISRA $($ India $) \quad=\mathbf{3 . 1 1 7}$ SIS $($ USA $) \quad=\mathbf{0 . 9 1 2}$ ICV $($ Poland $) \quad=6.630$

\begin{tabular}{|c|c|c|c|c|c|c|}
\hline mpact Factor: & $\begin{array}{l}\text { ISI (Dubai, UAE } \\
\text { GIF (Australia) } \\
\text { JIF }\end{array}$ & $\begin{aligned} & =0.829 \\
& =0.564 \\
& =1.500\end{aligned}$ & $\begin{array}{l}\text { РИНЦ (Russia) } \\
\text { ESJI (KZ) } \\
\text { SJIF (Morocco) }\end{array}$ & $\begin{array}{l}=0.156 \\
=8.716 \\
=5.667\end{array}$ & $\begin{array}{l}\text { PIF (India) } \\
\text { IBI (India) } \\
\text { OAJI (USA) }\end{array}$ & $\begin{array}{l}=1.940 \\
=4.260 \\
=0.350\end{array}$ \\
\hline
\end{tabular}

